Politics and Society in Britain 
Also by Michael Moran

The Union of Post Office Workers: a study in political sociology

The Politics of Industrial Relations

The Politics of Banking 


\title{
Politics and Society in Britain
}

\author{
An Introduction
}

\author{
Michael Moran
}

\author{
St. Martin's Press New York
}


(C) Michael Moran 1985

Softcover reprint of the hardcover 1st edition 1985 978-0-333-36137-5

All rights reserved. For information, write:

St. Martin's Press, Inc., 175 Fifth Avenue, New York, NY 10010

Published in the United Kingdom by Macmillan Education Ltd.

First published in the United States of America in 1985

ISBN 978-0-333-36138-2 ISBN 978-1-349-17962-6 (eBook)

DOI 10.1007/978-1-349-17962-6

Library of Congress Cataloging in Publication Data

Moran, Michael.

Politics and society in Britain.

Bibliography: $p$.

Includes index.

1. Great Britain - Politics and government - 1945-

2. Great Britain - Social conditions - 1945-

I. Title.

JN231.M67 $1985 \quad 320.941 \quad 85-11718$ 
For my mother and in memory of my father 


\section{Contents}

List of Tables and Figures ix

Acknowledgements $\quad$ x

Preface $\quad$ xi

1 The Changing Social Structure 1

Outline 1

The First Industrial Nation 2

Centralisation and the Rise of Class $\quad 7$

Equality and Inequality $\quad 12$

Economic Markets and Social Change 24

Class: Persistence, Fragmentation or Realignment? 28

Conclusion $\quad 32$

2 Political Culture and Political Instability 33

Outline 33

Nature of Political Culture 34

The Civility Model 35

Objections to the Civility Model 36

Alternatives to the Civility Model 38

Northern Ireland: A Case Study of Instability 49

Conclusion $\quad 57$

3 Elections and Electors $\quad 58$

Outline 58

Who Votes? 59

Class and the British Elector $\quad 62$

The New Electorate $\quad 68$

The Outcome of Elections $\quad 75$

Explaining Electoral Change 81

Conclusion $\quad 85$ 
4 The Political Parties 86

Outline 86

Parties: Organisation and Power $\quad 87$

Parties and Their Ideologies $\quad 97$

Parties, Members and Activists $\quad 105$

Minor Parties 113

Parties in Decline $\quad 117$

Conclusion $\quad 119$

5 Pressure Group Politics 120

Outline $\quad 120$

The Nature of Groups $\quad 120$

Functional Groups: Capital, Labour, Professions 125

Preference Groups and Power 138

Understanding Pressure Group Politics 144

Conclusion 149

6 Rulers and Representatives 150

Outline $\quad 150$

The Study of Elites 151

Political Elites 153

Administrative Elites $\quad 161$

Economic Elites $\quad 167$

Elites in Britain: Variety, Change and Stability 169

Power, Ceremony and Secrecy 175

Conclusion $\quad 180$

7 The Decline of the British State 182

Outline $\quad 182$

The Decline of the British State 182

The New Economic Order $\quad 188$

The End of Britain? 199

Recommended Reading 205

References $\quad 210$

Index 221 


\section{List of Tables and Figures}

\section{Tables}

1.1 English dominance in the British Isles, 1980s 5

1.2 Regional and national inequality in Britain in the 1980s 9

1.3 Numbers employed in public and private sectors, 1961 and 1982

1.4 Changes in housing tenure, United Kingdom, 1914-82

3.1 Popular votes and parliamentary representation, 1959 and 1983

6.1 Education and occupations of MPs

6.2 Education and class origins of Cabinet Ministers, 1916-84

6.3 Social and educational background of civil servants

6.4 Per cent of selected administrative elites educated at fee-paying schools, 1939-83

6.5 The financial elite, 1983

\section{Figures}

1.1 Trends in infant mortality rates for main occupational classes, $1930-80$

1.2 Inequalities in earnings, 1913-78

1.3 Trends in the distribution of personal wealth, 1923-76

3.1 Class composition of Conservative and Labour Party support .

3.2 Two-party share of vote, $1945-83$

3.3 Where parties lose and gain votes between one election and the next

6.1 The variety of elites in Britain 


\section{Acknowledgements}

I am grateful to David Howell, to Tim May and to three anonymous Macmillan referees for valuable comments on an earlier draft of this book. I learned a great deal from the experience of teaching British Politics with Tim May at Manchester Polytechnic and, latterly, from teaching the same subject with Lewis Minkin; to both I give warm thanks. Martin Burch and Bruce Wood advised me on important particular points. Steven Kennedy was a patient and encouraging editor. The considerable labour of typing successive drafts was done by Lynn Dignan, Karen Hall, Juliet Rodgers, Catherine Smith, Gillian Wooley and Joyce Wolfson: my thanks to them all.

Textbooks are shaped by the experience of teaching. My greatest debt is to the successive generations of students at Manchester Polytechnic and the University of Manchester who have taken my courses since 1970 .

Victoria University of Manchester

Michael Moran

The author and publishers are grateful for permission to reproduce the following copyright material: Her Majesty's Stationery Office for permission to use extracts from tables in Cmnd. 7595 (1979-80), Cmnd 7679 (1979-80), Inequalities in Health (1980), 1980 Mortality Statistics (1983), Social Trends (1984); to the authors and to Cambridge University Press for permission to use part of Table 3.6, p. 90, of B. Särlvik and I. Crewe, Decade of Dealignment (1983). The quotations at the heads of chapters, and of section 6 of Chapter 2, are taken from the King James Bible. 


\section{Preface}

This book is designed to give an introduction to the social fabric of British politics. Its range is therefore narrower but its intended penetration deeper than is usual with introductory texts. The ideal reader will already be studying Britain at an elementary level - for instance, on the early stages of a degree or in the later stages of ' $A$ ' level - and will thus know something of the bare institutional outlines of the British system of government. The book largely ignores these familiar outlines, concentrating instead on organisations and processes beyond the range of formal institutions. The work is conventionally organised to cover conventional topics. Chapter 2 examines the changing shape of popular political values in Britain, the connection between those values and political stability, and the particular problem of political stability in Northern Ireland. Chapter 3 examines the changing structure of the electorate, the changing influences shaping individual electoral choice, and the way individual choice, the composition of the electorate and electoral rules combine to produce election results. Chapter 4 describes organisation, ideology and membership of the three main party institutions now dominant in Britain - Conservative, Labour and the 'Alliance' of Liberals and Social Democrats. Thumb-nail sketches are also offered of a range of minority parties. Chapter 5 offers a definition and classification of groups, describes how groups operate and estimates the power of different groups. Chapter 6 examines the social composition and political culture of elites in Britain. It begins by defining elites as small minorities occupying prominent positions in institutions, and then discusses the case for studying their social and educational origins. This is followed by an examination of the 


\section{xii Preface}

changing pattern of recruitment at the top of political parties, administrative institutions and elites in the economy.

These chapters form the political core of the book. But it is a truism that the politics of a country are deeply influenced by the social context in which they are conducted. The first and last chapters examine this context. States are surrounded by two very different social environments. The more immediate and noticeable is provided by domestic society. Chapter 1 examines the changing structure of British society. It looks at the historical development of the economy, the changing scale of organisation, the balance between equality and inequality, and the social impact of developing economic markets. But the British state operates not only in British society; it is also a member of a world society populated by other states and by international institutions. This second social context is often neglected in the study of British politics, yet the changing organisation of world society and Britain's altered place in it are central to the condition of our country today. Just over a century ago Britain dominated world society; now she has been relegated to a position of comparative insignificance. The decline of the British state in world society, and its domestic implications, are the concern of the last chapter.

Arguments about the relationship between politics and the wider social context raise some of the most intractable and abstract issues in the social sciences. To what degree, for instance, are political institutions shaped by economic structures? Do political ideas exercise an independent force on political action? Is political change determined by broad historical forces or by the decisive intervention of outstanding personalities? These issues are neglected in this book, not because they are unimportant but because they are too important to be tackled as a subsidiary part of a work whose main purpose is to provide a bread-and-butter summary of evidence about changing values and organisations. The book does not pretend, however, to be plainly descriptive. Although part of the purpose of studying politics is to encourage dispassionate assessment of evidence, 'facts' in politics rarely point decisively to particular conclusions. A body of evidence only begins to make sense when we try to fit it to alternative theories or models. One aim of the succeeding chapters is to describe some of the available alternative models: to ask, for instance, how far changing political values in Britain are the product of the rise of a 'post-affluent' or of a 'populist' culture; how far the 'class model' of 
British voting behaviour has been superseded; how far a 'corporatist' model makes sense of the changing organisation of pressure groups.

All these questions raise the issue of how far British politics has altered and continues to alter. This fascination with change is the product of our present political condition. The extensive academic study of British politics dates only from the 1950s and 1960s. Most of those now teaching and writing either began work in those decades or were educated by people and books formed by the experience of that time. Tranquillity, continuity with the past, and decisive government were the most commonly noticed features of British politics in those innocent years. The succeeding decades have been dominated by images of violence, the decay of established institutions, and the multiplication of government failures. These are the images; the succeeding pages examine how far they fit reality. 